\title{
APLIKASI TICKET SYSTEM UNTUK ENGINEERING TEST SERVICE (ETS) PADA PT. HONEYWELL AEROSPACE INDONESIA
}

\author{
Omri Nainggolan', Muhammad Faizal ${ }^{2}$, Muhammad Saleh ${ }^{3}$ \\ 1,3 Jurusan Teknik Informatika STT Indonesia Tanjungpinang \\ Jln. Poma Air No. 28 Tanjungpinang Kepulauan Riau Indonesia \\ ${ }^{1}$ omri11ngl@gmail.com \\ ${ }^{2}$ faizal@sttindonesia.ac.id \\ ${ }^{3}$ saleh@sttindonesia.ac.id
}

\begin{abstract}
Intisari- Sistem manajemen Engineering Test Service Activity pada perusahaan yang dilakukan masih belum terstruktur dan dengan proses manual akan menyebabkan system penyimpanan data Ticket dan Repair maupun data perawatan (Preventive Maintenance) serta data Calibration, juga pencarian data serta pembuatan sangat memakan waktu yang lama. Hal ini tentu akan sangat merugikan perusahaan karena akan berdampak pada output produksi sehingga kurang memuaskan semua perusahaanperusahan asing yang menjadi pelanggan PT. Honeywell Aerospace Indonesia yang merupakan perusahaan bergerak dalam bidang eletronik untuk pembuatan instrument navigasi pesawat terbang.

Penelitian ini dimaksudkan untuk membangun suatu program aplikasi yang paling diminati dan popular untuk mempercepat terlaksananya suatu proses. Program aplikasi yang digunakan dibangun dengan metode inputan yang terstruktur dan juga yang secara otomatis sudah ada dan tinggal mencetak saat di butuhkan. Aplikasi manajemen Engineering Test Service (ETS) Activity dapat memberikan hasil yang baik dalam pengolahan data yang dibutuhkan. Sofware yang digunakan oleh penulis sebagai alat bantu dalam penelitian ini adalah Applikasi Program Visual Basic Access database. Hasil akhir dari penelitian adalah berupa suatu program aplikasi yang dapat mengolah data dan menyajikan data secara instan dengan hanya klik dengan form menu satu untuk semua (one for all).
\end{abstract}

Kata kunci- Engineering Test Service (ETS), Ticket System, PT. Honeywell Aerospace Indonesia.

Abstract- The Engineering Test Service Activity management system in the company that is carried out is still not structured and with manual processes it will cause Ticket and Repair data storage systems as well as Preventive Maintenance and Calibration data, as well as data search and manufacture are very time consuming. This of course will be very detrimental to the company because it will have an impact on production output so that it does not satisfy all foreign companies that are customers of PT. Honeywell Aerospace Indonesia, which is a company engaged in the electronics sector for the manufacture of aircraft navigation instruments.

This research is intended to build an application program that is most popular and popular to speed up the implementation of a process. The application program used is built with a structured input method and also automatically exists and only prints when needed. The Engineering Test Service (ETS) Activity management application can provide good results in processing the required data. The software used by the author as a tool in this study is the Visual Basic Access Database Program Application. The final result of the research is in the form of an application program that can process data and present data instantly with just a click with the menu form one for all (one for all).

Keywords—Engineering Test Service (ETS), Ticket System, PT. Honeywell Aerospace Indonesia.

\section{Pendahuluan}

Perkembangan teknologi komputer, menjadikan komputer sebagai suatu media sarana penting dalam dunia teknologi informasi. Komputer dapat mengolah data yang diinginkan sesuai dengan kebutuhan suatu instansi atau perusahaan. Salah satu manfaat komputer adalah penerapan komputer pada sistem informasi suatu perusahaan pemerintah maupun swasta yang sangat dibutuhkan karena perkembangan teknologi yang sangat pesat menuntut suatu perusahaan untuk memperoleh informasi yang lebih cepat dan akurat. Sistem informasi yang mendukung membuat kinerja suatu perusahaan akan terlaksana dengan baik dan dapat menangani berbagai pengolahan data dengan menggunakan teknologi informasi. Adanya sistem informasi yang tepat dan akurat dapat mengurangi terjadinya kesalahan yang tidak diinginkan sehingga

dapat meningkatkan kinerja yang lebih efisien dan kecepatan operasional suatu perusahaan.

Dalam menjalan Usaha tersebut Selain dibutuhkannya sumber daya manusia yang handal dalam pengelolaan usaha tersebut, kemajuan teknologi juga berperan dalam meningkatkan kemajuan usaha tersebut. Sampai saat ini proses engineering test service PT. Honeywell Aerospace Indonesia yang masih menggunakan cara manual.

Dalam hal ini penulis tertarik untuk melakukan penelitian Skripsi pada proses engineering test service activity di bagian departemen Engineering Test Service dimana penulis yang juga salah satu karyawan pada perusahaan ini berniat untuk merancang suatu sistem terintegrasi dalam proses engineering 
test service activity di PT.Honeywell Aerospace Indonesia dengan memilih judul "Aplikasi Ticket System untuk Engineering Test Service (ETS) Pada PT. Honeywell Aerospace Indonesia".

Program aplikasi yang dirancang dapat mengolah data dan menyajikan data secara instan dengan hanya klik dengan form menu satu untuk semua (one for all). dari sistem ini diharapkan memberikan potensi kerja yang sangat baik, cepat, akurat dan efisien bagi para karyawan dan perusahaan yaitu Salah satu perusahaan swasta asing manufaktur anak usaha Honeywell International asal Amerika Serikat yang hingga saat ini sedang beroperasi di Indonesia yakni PT. Honeywell Aerospace Indonesia yang terletak di Jl. Teratai Lot D-16 Kawasan Bintan Inti Industrial Estate Lobam, merupakan sebuah perusahaan yang bergerak dibidang teknologi Aerospace yakni elektronik pesawat terbang.latar belakang masalah, tinjauan pustaka secara ringkas, maksud dan tujuan riset dilakukan.

\section{Metodologi Penelitian}

Dalam kegiatan untuk memperoleh data pada penelitian Skripsi ini pada PT. Honeywell Aerospace Indonesia yang beralamat di J1. Teratai Lot D 16, D27 BIIE Lobam Bintan Kepulauan Riau, penulis menggunakan teknik pengumpulan data yang digunakan adalah sebagai berikut :

A. Observasi

Melakukan observasi atau peninjauan tempat sebelum pelaksanaan kegiatan pengumpulan data dengan mengadakan pengenalan terhadap objek Skripsi, aktivitas kerja dan bahan kajian.

B. Wawancara

Melakukan wawancara secara langsung dengan pihakpihak yang terlibat dalam sistem.

C. Studi Kepustakaan

Melakukan pengumpulan data secara tidak langsung dengan melakukan studi kepustakaan, yaitu dengan mengumpulkan data-data dan teori-teori yang berhubungan dengan penulisan laporan Skripsi ini.

D. Metode Pengembangan Sistem.

Metode pengembangan perangkat lunak yang digunakan dalam membangun sistem informasi ini menggunakan model Waterfall (Classic Life Cycle) yang menyarankan pengembangan sistem secara sistematik dan berurutan yang dimulai dari tingkatan sistem tertinggi dan berlanjut ke tahap analisis, desain, pengkodean, pengujian dan pemeliharaan. Kelebihan dari metode ini adalah terstruktur, dinamis, dan sequential.
Metode Waterfall dapat di lihat pada gambar 2.4:

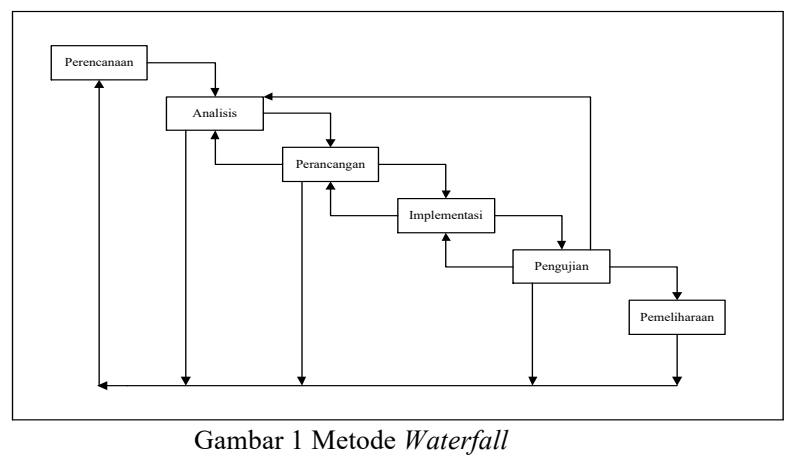

Tahapan model Waterfall adalah sebagai berikut:

a. Engineering System (Perencanaan)

Tahap dimana melakukan pengumpulan data dan menentukan kebutuhan-kebutuhan bagi seluruh elemen-elemen sistem.

b. Analysis (Analisis)

Tahap analisis adalah tahap pengumpulan seluruh kebutuhan elemen di tingkat perangkat lunak (requirement analysis). Sehingga dapat ditentukan data (informasi yang saling terkait), fungsi, proses dan prosedur yang diperlukan beserta unjuk kerjanya, dan antarmuka (User Interface). Hasil akhir dari tahap analisis adalah mendapatkan seluruh spesifikasi kebutuhan perangkat lunak.

c. Design (Perancangan)

Tahap ini merupakan tahap untuk menerjemahkan seluruh spesifikasi perangkat lunak yang telah didapat pada tahap analisis ke dalam bentuk arsitektur perangkat lunak yang memiliki karakteristik mudah dimengerti dan tidak sulit untuk diimplementasikan.

d. Code (Pemrograman)

Proses penerjemahan data atau pemecahan masalah ke dalam baris-baris kode program yang dapat dimengerti oleh mesin (komputer).

e. Test (Pengujian)

Tahap pengujian digunakan untuk memeriksa apakah perangkat lunak yang dibuat sudah sesuai dengan spesifikasinya atau tidak. Pengujian juga berguna untuk mengetahui apakah hasil implementasi telah bebas dari kesalahan program (error free), baik kesalahan logika maupun kesalahan sintaks. Tahap pengujian dilakukan pada setiap modul. Sehingga jika modul tidak bermasalah dan lulus uji, maka seluruh modul telah selesai diuji akan diintegrasikan dan dikompilasi sehingga membentuk suatu perangkat lunak yang utuh.

f. Operational and Maintenance (Pengoperasian dan Pemeliharaan)

Tahap ini ditandai oleh penyerahan perangkat lunak kepada pemesan perangkat lunak, untuk kemudian dioperasikan oleh pemiliknya. Suatu kesalahan atau 
kegagalan dalam pelaksanaan fungsi mungkin saja terjadi pada masa operasional sehari-hari.

\section{HASIL DAN PEMBAHASAN}

Perancangan sistem secara umum bertujuan untuk memberikan gambaran secara umum kepada pemakai sistem yang baru dan juga merupakan persiapan dari rancangan terperinci dengan mengidentifikasi komponen - komponen sistem informasi.

Rancangan ini meliputi Flowmap yang diusulkan, Flowchart Proses Metode Ticket System, Diagram Konteks, Data Flow Diagram, Entity Relationship Diagram, Struktur Program, Rancangan Input, Rancangan Proses dan Rancangan Output.

A.Analisis Prosedur Data Member Baru Usulan.

Berikut adalah prosedur data member baru yang sedang berjalan :

1. Teknisi memberikan form data member baru kepada karyawan yang telah diterima masuk perusahaan oleh bagian HRD.

2. Karyawan baru mengisi form data member ETS.

3. Form yang sudah diisi di berikan kepada Sr Engineer.

4. Engineer melakukan pemeriksaan, jika data member baru sudah lengkap sesuai kriteria pada bagian ETS maka $\mathrm{Sr}$ Engineer memperoses tandatangan.

5. Jika data karyawan baru tidak lengkap data member baru akan dikembalikan kepada Karyawan.

6. Form Member yang sudah di tandatangan kemudian diberikan kepada teknisi.

7. Teknisi menginput data Member baru langsung ke dalam sistem ETS database.

8. Kemudian Teknisi mencetak laporan Tester baru setiap bulannya dan di berikan kepada Sr Engineer untuk review.

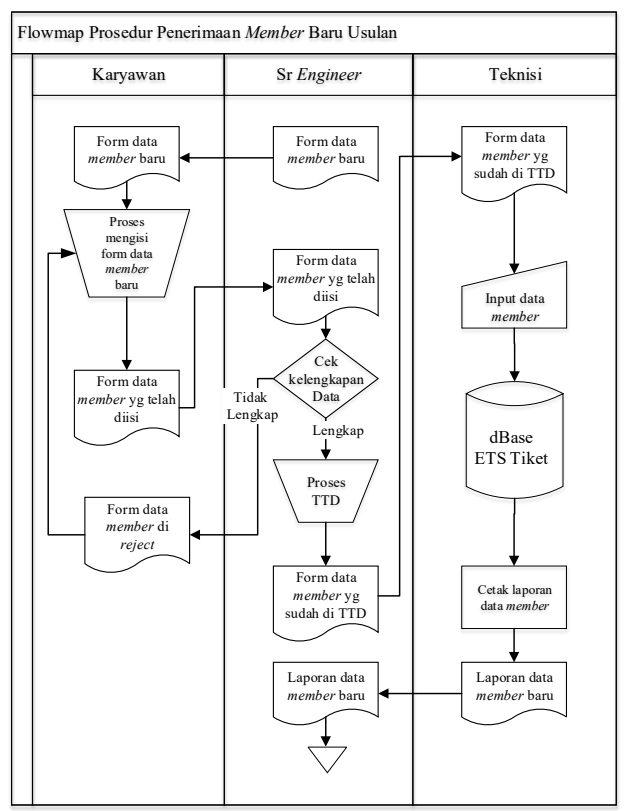

Gambar 2 Flowmap Data Member Baru Usulan
B. Analisis Prosedur Penyerahan (Create) ETS Tiket Yang diusulkan pada PT. Honeywell Aerospace Indonesia

a. Prosedur pembuatan tiket pengaduan ETS Tiket yang diusulkan pada PT. Honeywell Aerospace Indonesia sebagai berikut :

b. Karyawan yang mengoperasikan tester dan tibatiba mengalami kerusakan tidak perlu lagi mengisi formulir ETS tiket yang lama.

c. Karyawan lansung membuka sistem kemudian menginput data kerusakan tester sistem ETS Tiket yang berisi nama karyawan serta detail tester atau equipment, nama, nomorseri (KSN), manufacturing, model dan gejala atau masalah seperti kerusakan atau gangguan, juga lokasi tester atau equipment.

d. Data kerusakan tester yang telah diinput pada sistem kemudian akan secara otomatis tampil di dashboard ETS Tiket System.

e. Petugas engineering (teknisi) kemudian melakukan proses pemeriksaan (verification) terhadap ETS Tiket tersebut apakah sudah sesuai pada kriteria activity repair perbaikan ataupun tidak ada kondisi yang perlu di perbaiki (repair).

f. Jika data pada ETS Tiket tidak sesuai kriteria perbaikan (repair) atau sama sekali tidak ada kondisi yang harus di repair atau di perbaiki, petugas atau teknisi akan menghapus data tersebut dari sistem.

g. Dan jika data pada ETS Tiket sesuai kriteria perbaikan (repair) maka petugas (teknisi) menyatakan ETS Tiket tersebut sah yang kemudian teknisi akan lansung pergi ke produksi untuk melakukan perbaikan (repair).

h. Petugas (teknisi) juga akan membuat suatu laporan berkas data ETS Tiket yang belum di close pada dashboard sistem yang belum memperoleh hasil proses pemeriksaan (verification). 


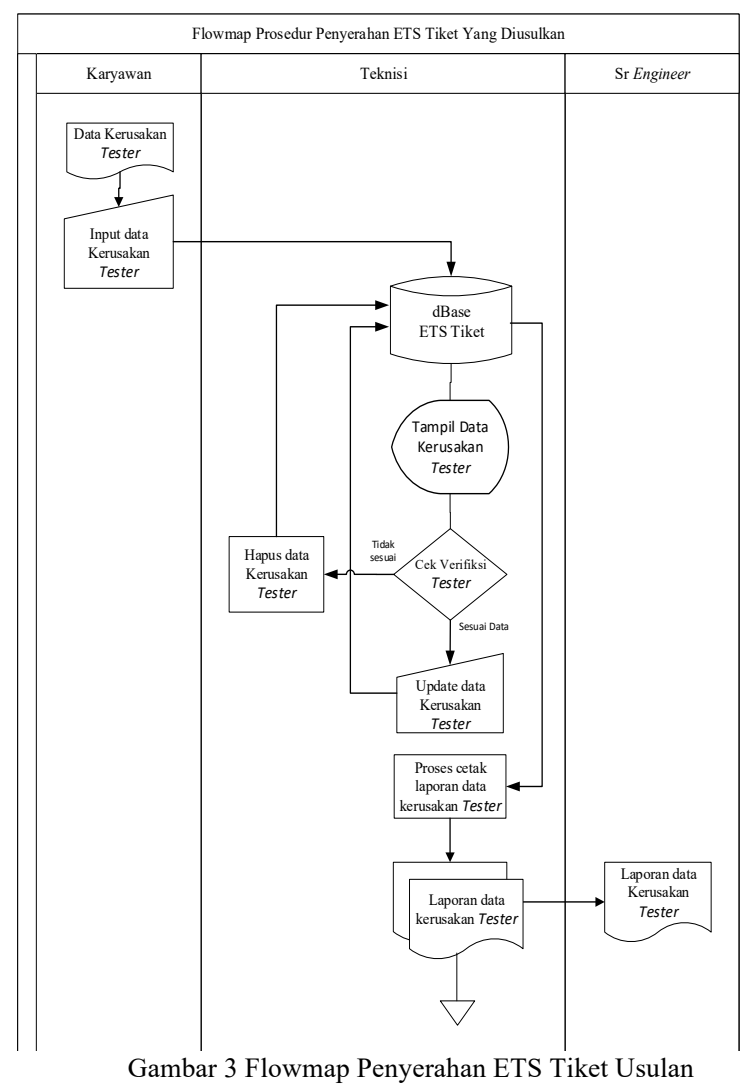

C. Analisis Prosedur Perbaikan Tester dan Closing Tiket Yang diusulkan pada PT. Honeywell Aerospace Indonesia

1. Setiap data pada ETS Tiket yang sudah diberikan oleh karyawan dan telah diverifikasi oleh petugas (teknisi) akan masuk dalam proses penanganan masalah melalui aktivitas perbaikan (repair) dengan metode First In First Process (FIFP) yang mana poin awal adalah yang pertama di proses dan seterusnya sesuai dengan urutan masuknya nomor ETS Tiket yang dilakukan secara otomatis.

2. Proses perbaikan (repair) diawali dengan penentuan dengan pengecekan atau verifikasi jenis kerusakan atau masalah kemudian meganalisa apakah kerusakan hardware atau software.

3. Kemudian teknisi dalam hal ini langsung melakukan proses perbaikan dan segala analisa dan semua tindakan penyelesaian yang telah dilakukan sehingga tester (equipment) dapat berfungsi seperti normal lansung diinputkan pada database.

4. Kemudian ETS Tiket tersebut akan di closing (tutup) dengan cara submit pada form menu update yang menyatakan telah sukses diperbaiki.

5. Kemudian sistem dashboard pada menu database yang berada di produksi akan ter-update dengan otomatis kasus tiket yang telah di submit akan hilang dari tampilan dashboard yang menyatakan bahwa tiket telah di closed dan equipment telah berhasil diperbaiki.

6. Teknisi akan membuat laporan data perbaikan semua mesin (equipment) secara berkala dan disajikan sesuai permintaan secara lansung kepada Sr Engineer untuk di review.

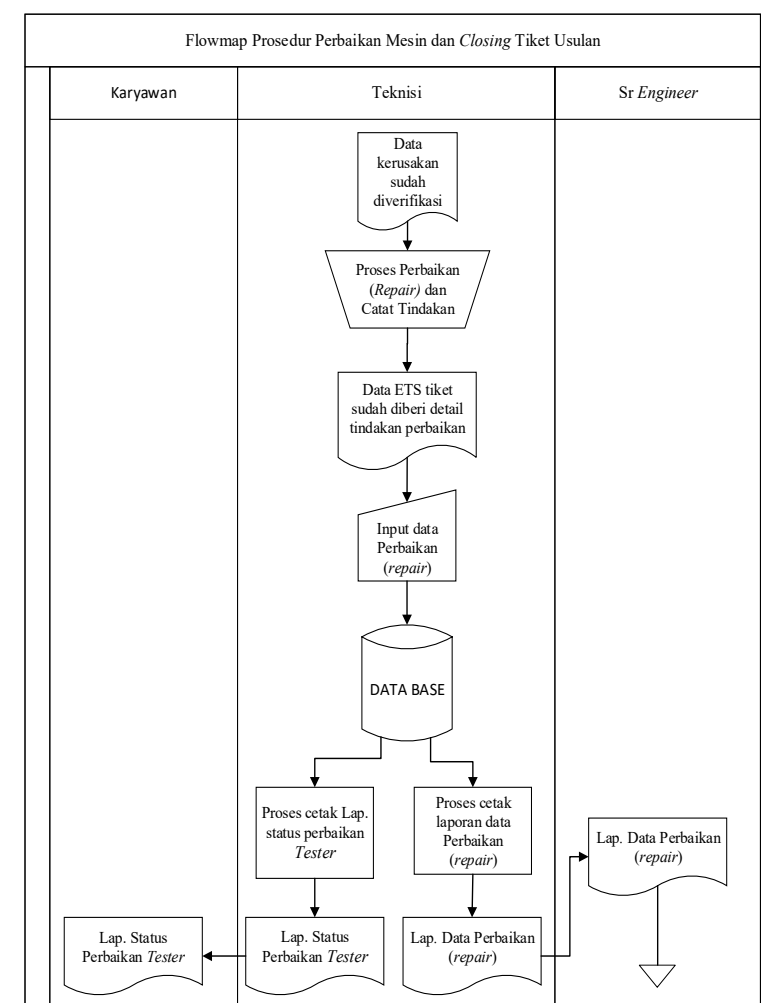

Gambar 4 Flowmap Prosedur Perbaikan Mesin dan Closing Tiket Usulan

D. Analisis Prosedur Pendaftaran Tester (Equipment) Baru Usulan.

Berikut adalah prosedur Pendaftaran Tester (Equipment) baru yang sedang berjalan :

1. Vendor memberikan data spesifikasi Tester baru kepada Teknisi.

2. Teknisi pun mengecek data-data Tester yang telah diberikan oleh Vendor.

3. Data spesifikasi diperiksa sesuai kelayakan Tester dan jika tidak sesuai kriteria standard Tester yang akan digunakaan maka akan dikembalikan kepada vendor dan dinyatakan sebagai data spesifikasi reject.

4. Jika data spesifikasi Tester telah sesuai dan tidak ada kerusakan pada Tester maka Teknisi menginput data Tester baru ke komputer langsung ke dalam sistem ETS database.

5. Kemudian Teknisi mencetak laporan Tester baru setiap bulannya dan di berikan kepada $\mathrm{Sr}$ Engineer untuk review. 


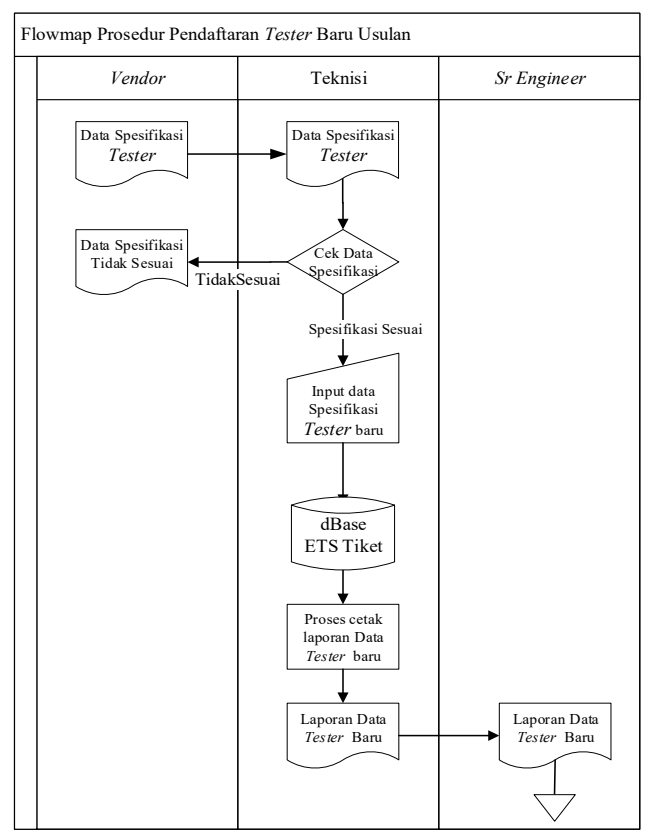

Gambar 5 Flowmap Pendaftaran Tester Baru Usulan

\section{E. Diagram Konteks}

Diagram konteks adalah diagram yang menggambarkan hubungan antara entitas eksternal dengan sistem. Dimana data yang diinputkan oleh bagian entitas eksternal akan diproses di dalam sistem dan akan menghasilkan laporan yang diinginkan oleh entitas eksternal tersebut.

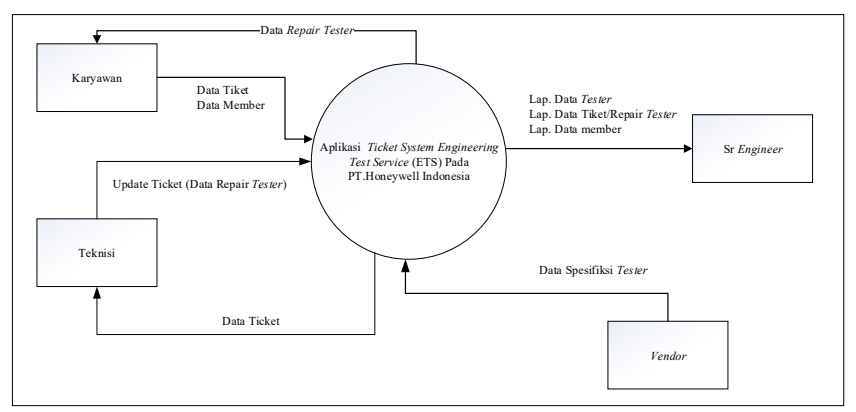

Gambar 6 Rancangan Diagram Konteks

\section{F. Data Flow Diagram}

Data Flow Diagram (DFD) adalah diagram yang digunakan untuk menggambarkan suatu sistem yang sudah jadi atau sistem yang baru dirancang yang akan dikembangkan secara logika, tanpa mempertimbangkan lingkungan fisik kemana data tersebut disimpan. Disamping itu Data Flow Diagram (DFD) juga dapat menggambarkan arus data yang terstruktur dan jelas dari mulai pengisian data sampai dengan keluarannya.

Diagram arus data mempunyai level atau tingkatan, level 0 merupakan diagram arus data yang mendasar dari sebuah proses, sedangkan level 1 dan seterusnya adalah merupakan pengambangan dari proses-proses yang ada pada level 0 yang bertujuan untuk lebih dimengerti dan dipahami. Untuk lebih jelas dapat dilihat pada gambar dibawah ini :

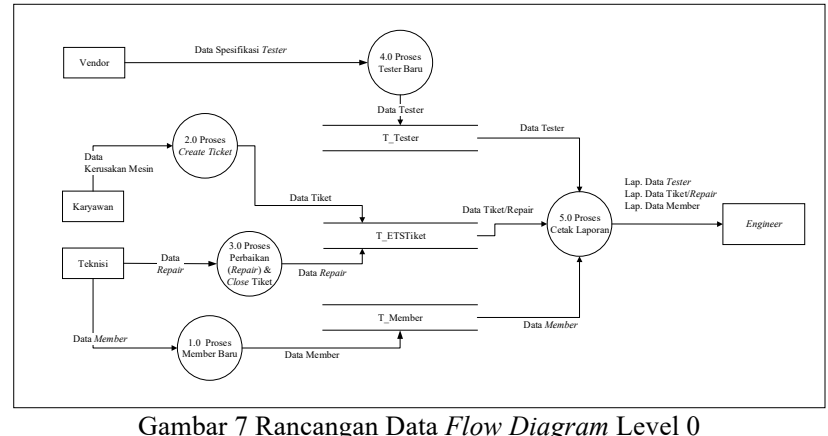

Dari DFD Level 0 diatas terdapat enam proses yang dapat dijabarkan berikut:

1. Proses 1.0 adalah proses member baru yang langsung dihubungkan dengan T_Member.

2. Proses 2.0 adalah proses create ticket yang langsung diproses oleh sistem untuk proses pembuatan tiket yang dihubungkan dengan T_ETS Tiket.

3. Proses 3.0 adalah proses perbaikan (repair) dan close atau update tiket yang langsung dihubungkan dengan $\mathrm{T}$ ETS Tiket.

4. Proses 4.0 adalah proses mesin baru yang langsung dihubungkan dengan $\mathrm{T}$-Tester.

5. Proses 5.0 adalah proses cetak yang akan mencetak laporan kepada Sr Engineer.

\section{G. Entity Relationship Diagram (ERD )}

Entity Relationship Diagram (ERD) atau Diagram antar Entitas adalah suatu diagram yang menggambarkan hubungan objek data yang disimpan yang ada dalam suatu sistem secara konseptual.

Objek Data adalah objek yang dapat dicatat atau direkam atau segala sesuatu yang ada dan dapat dibedakan entitas dapat berupa orang, benda, tempat, peristiwa atau konsep yang bisa diolah untuk menghasilkan informasi, rancangan, diagram entitas ini dibuat menurut data yang ada sehingga dapat menjelaskan hubungan data-data.

Atribut yang berhubungan dengan perangkat lunak Aplikasi Ticket System untuk Engineering Test Service (ETS) pada PT. Honeywell Aerospace Indonesia sebagai berikut:

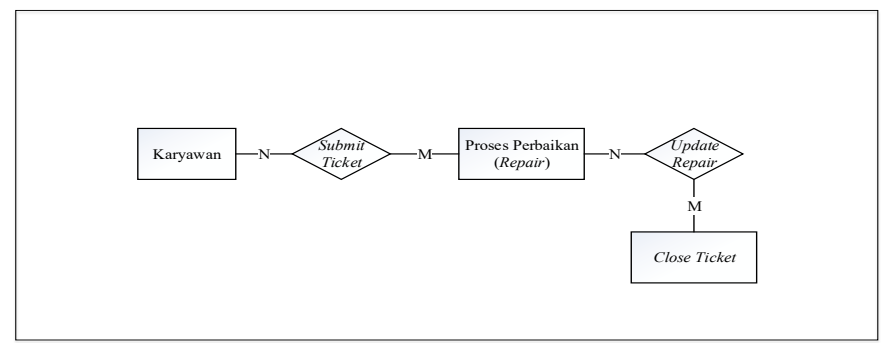

Gambar 8 ERD Sistem Informasi ETS Tiket 


\section{KESIMPULAN}

1. Berdasarkan hasil implementasi Aplikasi ETS Ticket System pada perusahaan yang bergerak di bidang pembuatan (produksi) elektronik pesawat PT. Honeywell Bintan, yang penulis kerjakan dapat disimpulkan sebagai berikut :

2. Aplikasi ETS Ticket System di PT Honeywell Indonesia Bintan sudah menggunakan tempat penyimpanan data berupa database yang terstruktur dan tidak menghabiskan ruang penyimpanan, sehingga kesulitan-kesulitan yang terjadi selama ini pada sistem lama seperti kesalahan pencarian data yang berhubungan dengan penyimpanan data dapat di atasi.

3. Aplikasi ETS Ticket System dapat mengefesiensikan waktu aktivitas engineering test service, membuat (penyerahan) tiket dan meng-update tiket tidak lagi mengggunakan kertas sehingga dapat menghemat pembelian kertas, serta dalam membuat laporan, laporan yang dibuat tidak lagi harus mengetik manual dalam pembuatannya, aplikasi Aplikasi ETS Ticket System yang penulis buat sudah bisa dengan otomatis meng-export to Microsoft excel sehingga dengan Kelancaran aktivitas engineering test service tentunya sangat membantu jalannya aktivitas bagian produksi PT. Honeywell Indonesia Bintan.

\section{REFERENSI}

[1] Adi Nugroho, Analisis dan Perancangan Sistem Informasi dengan Metodologi Berorientasi Objek, Informatika, 2014, Bandung.

[2] Abdullah, Ma'ruf. 2014. Manajemen dan Evaluasi Kinerja Karyawan. Yogyakarta: Aswaja Pressindo.

[3] Anonim. Panduan Kerja Praktek dan Skripsi STT Indonesia, 014, Tanjungpinang.

[4] Al-Bahra bin Ladjamudin, Analisis dan Desain Sistem Informasi, [Graha Ilmu , 2012, Yogyakarta], hal.1

[5] Azhar Susanto, Sistem Informasi Akuntansi, [Linggar Jaya, 2010, Bandung], hal.46

[6] Edy Winarno ST,M,Eng, Ali Zaki dan Smit Dev Community, Belajar pemograman VB 6 dalam sekejap.

[7] Hengky Alexander Mungkulo, 212 Tip \& Trik Access 2010.

[8] HM Jogiyanto, Analisis dan Desain Sistem Informasi Edisi III, [Andi, 2011, Yogyakarta], hal.2

[9] http://www.seputarpengetahuan.com/definis-aplikasi-kom.html [ 15 September 2017, 19.00 WIB]

[10] Jurnal encepsupriatna.files/2010/02/flowmap.pdf http://ijns.org [18 September 2017, 10.22WIB]

[11] http://www.fairuzelsaid.com/konsep-dasar-sistem-basis-data.html[20 September 2017, $18.10 \mathrm{WIB}]$

[12] ui.academia.edu/MohammadAzwarAmat 2010 [25 September 2017 13.28 WIB]

[13] anonim, $2010 \mathrm{http} / /$ searchcrm.techtarget.com/definition/troubleticket.html [27 September 2017, 20.34 WIB]

[14] http://www.Intanstemapal.com/2014/08/pengertian-erd-entityrelationship.html[20 September 2017, 20.13 WIB]

[15] http://www. Materi belajar.com contoh-relasi-one-to-one-one-tomany.html[22 September 2017, 08.00 WIB]

[16] http://www.jewyner.com/2013/03/05/92/pengertiannormalisasi.html[24 September 2017,13.00 WIB] 